\title{
Nineteenth-
}

Century

Music Review

\section{Volume 6, Issue 1}

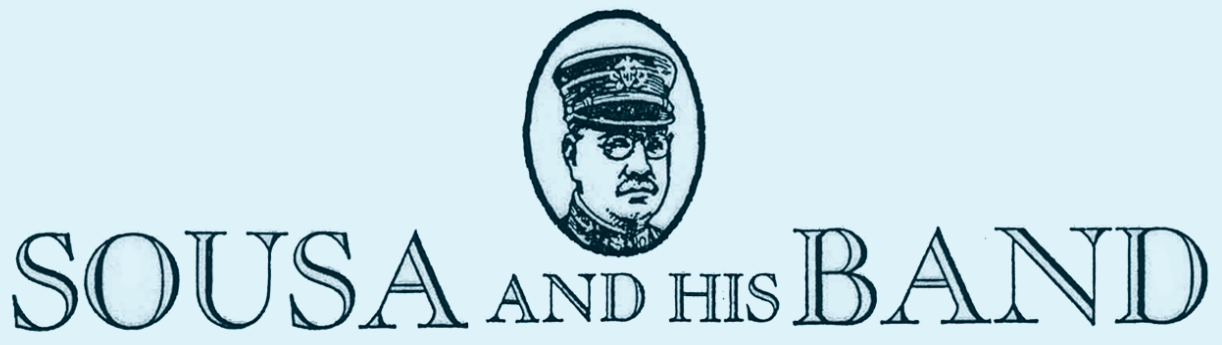

TABERNACLE-SaLt Lake City

Wednesday Afternoon, February 3, 1926

Lieut.-Commander JOHN PHILIP SOUSA, CoNductor HARRy Askin, Manager

GEo. D. Pyper, Local Manager

Miss Marjorie Moody, Soprano

Mr. William Tong, Cornet

Mr. George Carey, Xylophone

Mr. Howard Goulden, $X$ ylophone 


\section{Nineteenth-Century Music Review}

\section{VOLUME 6, ISSUE 1 \\ 2009}

\section{ASHGATE \\ Published in association with the Centre for Nineteenth-Century Music, Durham University, UK}


Letters to the Editor For any communication concerning published articles or reviews, please send letters by email or hard copy to the General Editor:

Professor Bennett Zon

School of Music

Durham University

Palace Green

Durham DH1 3RL

England

Email: bennett.zon@durham.ac.uk

Subscriptions For the latest information about the price of the journal and details of how to subscribe, please contact:

Nicky Staszkiewicz

Ashgate Publishing Limited

Wey Court East

Union Road

Farnham

Surrey GU9 7PT

England

Tel: $+44(0) 1252736693$

Fax: +44 (0)01252 736736

Email: journals@ashgatepublishing.com

\section{Themed Issues}

The General Editor of Nineteenth-Century Music Review encourages proposals from individuals with ideas for themed issues, involving the commissioning of up to six main articles per issue, as well as one or more review articles for coverage of books, CDs and scores. Those applying to the journal for this purpose should initially provide the General Editor with a statement of no more than 500 words, outlining the thematic nature of the proposed issue, the names of contributing authors along with a working title for their papers, and a timetable for submission of work.

Proposers of themed issues work alongside the General Editor, and are designated Guest Editors. They are responsible for commissioning, organizing and preparing articles for publication, as well as working closely with review editors to locate suitable material and authors for relevant sections of the journal. Review sections of themed issues are not exclusively thematicized, and tend towards a balance of half themed, and half general material.

Articles commissioned for themed issues follow the same process of peer review as general issues. No guarantee of publication can be given to specially commissioned authors. 


\title{
Nineteenth-Century Music Review
}

\author{
General Editor \\ Bennett Zon \\ Book Reviews Editor \\ Jim Sobaskie \\ CD Reviews Editor \\ Jeremy Dibble \\ Score Reviews Editor \\ Stephen Downes
}

\section{Editorial Board}

Professor Bennett Zon, Durham University UK (General Editor)

Professor Jeremy Dibble, Durham University (CD Reviews Editor)

Dr Stephen Downes, University of Surrey, UK (Scores Reviews Editor)

Dr Jim Sobaskie, Mississippi State University, USA (Book Reviews Editor)
Professor Anna Celenza, Georgetown University, USA

Professor William Weber, California State University, Long Beach, USA

Dr Phyllis Weliver, Saint Louis University, USA

\section{Advisory Board}

\section{Dr Rosamund Bartlett}

Professor Andrew Bowie, Royal Holloway, University of London, UK

Dr Geoffrey Chew, Royal Holloway, University of London, UK

Professor John Deathridge, King's College, University of London, UK

Professor Annegret Fauser, University of North Carolina, Chapel Hill, USA

Professor Peter Franklin, University of Oxford, UK

Dr Sophie Fuller

Professor Lydia Goehr, Colombia University, USA

Professor Thomas Grey, Stanford University, USA
Professor Hervé Lacombe, Université Rennes 2 - Haute Bretagne, France Professor Roberta Marvin, University of Iowa, USA

Professor Simon McVeigh,

Goldsmiths College, University of London, UK

Professor Julian Rushton, University of Leeds, UK

Professor Jim Samson, Royal

Holloway, University of London, UK

Professor Manuela Schwartz, Hochschule Magdeburg/Stendal (FH), Germany

Professor Nicholas Temperley, University of Illinois, USA 
All rights reserved. No part of this publication may be reproduced, stored in a retrival system, or transmitted in any form or by any means, electronic, mechanical, photocopying, recording or otherwise, without the prior permission of the publisher.

Published by

Ashgate Publishing Limited

Wey Court East

Ashgate Publishing Company

Union Road

Suite 420

Farnham

101 Cherry Street

Surrey GU9 7PT

Burlington, VT 05401-4405

England

This journal is the successor of the Music Review, founded by the late Geoffrey Sharp, which then continued for many years under the ownership of the late A.F. Leighton-Thomas.

www.ashgate.com

ISSN: 1479-4098

Bach musicological font developed by (C) Yo Tomita 


\section{Contents}

Volume 6, Issue 1

Notes on Article Contributors

vii

Articles

Katherine K. Preston

Introduction to the Issue

Francesco Izzo

William Henry Fry's Leonora: The Italian Connection

Patrick Warfield

John Esputa, John Philip Sousa, and the Boundaries of a

Musical Career

Aaron D. McClendon

Harmonizing the Nation: Margaret Fuller and the Music of

Antebellum America

Katherine K. Preston

Encouragement from an Unexpected Source: Louis Antoine Jullien,

Mid-Century American Composers, and George Frederick Bristow's Jullien Symphony

\section{REVIEWS}

Book Reviews

Marianne Tettlebaum

Bach's Cycle, Mozart's Arrow: An Essay on the Origins of Musical

Modernity by Karol Berger

Heather Platt

The Organ Music of Johannes Brahms by Barbara Owen

Mark A. Pottinger

Giacomo Meyerbeer and Music Drama in Nineteenth-Century Paris

by Mark Everist

Malcolm Miller

Richard Wagner's Zurich: The Muse of Place by Chris Walton 
Books Received

CD Reviews

Timothy Storey

Bairstow: Three Introits or Short Anthems; Jesu, the very thought of thee; Blessed city, heavenly Salem; Magnificat and Nunc dimittis in D (1906); Lord, thou hast been our refuge; If the Lord had not helped me; Let all mortal flesh keep silence; Magnificat and Nunc dimittis in G (1940); Five Poems of the Spirit; Save us, O Lord. Roderick Williams bar., Paul Provost org., Choir of St John's College, Cambridge, Britten Sinfonia, David Hill cond.

Jonathan Bellman

Grieg: Violin Sonata No. 1 in F major Op. 8; Violin Sonata No. 2 in

G major Op. 13; Violin Sonata No. 3 in C minor Op. 45; Solo piano miniatures arranged for violin and piano by Joseph Acron: At Home Op. 43 No. 3; Puck Op. 71 No. 3; Lonely Wanderer Op. 43 No. 2; Scherzo-Impromptu Op. 73 No. 2; Grandmother's Minuet Op. 68 No. 2; Dance from Jölster Op. 17 No. 3. Hagai Shaham vn, Arnon Erez pf

Peter Horton

Sterndale Bennett: Piano Concerto No. 4 in F minor Op. 19; Caprice in

E major Op. 22; Bache Piano Concerto in E major Op. 18.

Howard Shelley $p f /$ cond, BBC Scottish Symphony Orchestra

\section{Amanda Glauert}

Wagner: Siegfried. Jon Frederic West (Siegfried) ten; Heniz Göhrig

(Mime) ten; Wolfgang Schöne ('The Wanderer'/Wotan) bass;

Björn Waag (Alberich) bass; Attila Jun (Fafner) bass; Lisa Gasteen

(Brünnhilde) sop. Staatsoper Stuttgart, Staatsorchester Stuttgart,

Lothar Zagrosek cond

CDs Received

Score Reviews

Lars Franke

Johann Friedrich Reichardt, Schillers Lyrische Gedichte, edited by Rainer Gstein and Andreas Meier

Scores Received

Guidelines for Contributors 